\title{
A RAPID GROWTH OF VERRUCOUS CARCINOMA AFTER BIOPSY: TREATMENT AND RECONSTRUCTION
}

\author{
Angelica Gracia Budhipramono $\left.{ }^{1 *}\right)$ \& Sweety Pribadi ${ }^{2}$ \\ 1. Faculty of Medicine Pelita Harapan University, Tangerang, Banten, Indonesia \\ 2. Department of Plastic, Reconstructive and Aesthetic Surgery, Siloam Hospitals Lippo Village, Tangerang, Banten, Indonesia
}

\begin{abstract}
Summary: An increasing amount of evidence from clinical and experimental studies suggests that biopsies, thought to assist with definitive diagnoses, may aggravate tumor progression. We present a case of fast-growing giant verrucous squamous cell carcinoma, observed two weeks following biopsy. A 38-year-old man presented with a nose tumor that recurred two weeks after a biopsy and debridement to remove a lesion that was thought to be an abscess. Wide excision was performed on the tumor, frozen sectioned; the defect was reconstructed with a two-step forehead flap. The rapid tumor growth observed in this case raises the question of whether biopsies or other interventions may accelerate the growth of malignant tumors. Verrucous squamous cell carcinoma is slow-growing with a predilection for oral and nasal mucosa and rarely metastasizes. The patient presented here is an unusual case, with a tumor rapidly growing within fifteen days. A two-staged paramedian forehead flap is the workhorse of nasal reconstruction.

Even though the benefit of doing biopsies overall outweighs the potential side effects, further research is required to determine whether biopsies affect the progression of the tumor. Early differential diagnosis is also crucial, as it may affect the patient's plan of treatment and prognosis. Giant tumors on the facial area may cause a functional and cosmetic disturbance. A two-step forehead flap produces a satisfactory cosmetic appearance for the patient one-year post-procedure.
\end{abstract}

Keywords: Verrucous carcinoma; biopsy; rapid tumor growth; surgical flaps; nasal reconstruction.

\section{ABSTRAK}

Ringkasan: Semakin banyak bukti dari studi klinis dan eksperimental menunjukkan bahwa biopsi; yang dianggap membantu diagnosis pasti, dapat memperburuk perkembangan tumor. Di sini kami menyajikan kasus karsinoma sel skuamosa verukosa raksasa yang tumbuh cepat, diamati dua minggu setelah biopsi. Seorang pria berusia 38 tahun datang dengan tumor hidung yang kambuh dua minggu setelah biopsi dan debridemen untuk menghilangkan lesi yang dianggap abses. Eksisi luas dilakukan pada tumor, yang kemudian dilakukan potong beku; defek direkonstruksi dengan flap paramedian forhead dalam dua tahap.

Pertumbuhan tumor yang cepat yang diamati dalam kasus ini menimbulkan pertanyaan apakah biopsi atau intervensi lain dapat mempercepat pertumbuhan tumor ganas. Karsinoma sel skuamosa verukosa umunya tumbuh lambat dengan predileksi mukosa mulut dan hidung, dan jarang bermetastasis. Kasus yang disajikan di sini adalah kasus yang tidak biasa, dengan tumor yang tumbuh dengan cepat dalam waktu lima belas hari. Paramedian forehead flap dua tahap adalah metoda yang paling baik untuk rekonstruksi hidung.

Meskipun manfaat melakukan biopsi secara keseluruhan melebihi potensi efek sampingnya, penelitian lebih lanjut diperlukan untuk menentukan apakah biopsi memengaruhi perkembangan tumor. Diagnosis banding dini juga penting, karena dapat mempengaruhi rencana pengobatan dan prognosis pasien. Tumor raksasa di area wajah dapat menyebabkan gangguan fungsional dan kosmetik. Flap dahi dua langkah menghasilkan tampilan kosmetik yang memuaskan untuk pasien pasca prosedur satu tahun.

Kata Kunci: Karsinoma verukosa; biopsi; pertumbuhan tumor cepat; flap bedah; rekonstruksi hidung.

\section{Conflicts of Interest Statement:}

The Author (s) listed in this manuscript declare the absence of any conflict of interest on the subject matter or materials discussed. 


\section{INTRODUCTION}

Lauren V. Ackerman first described verrucous squamous cell carcinoma as a slowgrowing, well-differentiated, extensive, and invasive type of squamous cell carcinoma of the oral cavity. It is also known as Ackerman's tumor, or verrucous carcinoma (VC).1,2 The histologic feature of VC is deceptive, as it is much more similar to benign lesions such as verruca Vulgaris or another verrucous hyperplasia than squamous cell carcinoma. ${ }^{3}$ It is predominantly found in older adults in their fifth decade or older and tobacco users. ${ }^{3}$ Despite its invasive characteristic, metastases are very rare. VC can destroy the nose or mandible as it progresses into underlying tissues. ${ }^{3}$ In this report, we present a fast-growing, atypically located verrucous carcinoma, preceded by the diagnosis of inverted papilloma.

\section{CASE REPORT}

A 38-year-old man referred by a surgeon to the plastic surgery clinic presented with a tumor on the nose, which recurred two weeks after a biopsy and debridement to remove a lesion that was thought to be an abscess. The patient complained of difficulty in breathing from the left nostril, denied pain, and denied epistaxis. Histological evaluation of the initial debridement revealed inverted papilloma. Physical examination revealed a $4 \times 4 \times 2 \mathrm{~cm}$ tumor on the right nasal alae (Figures 1). CT scan of the recurred tumor showed a lobulated mass with heterogenous enhancement on the right anterior aspect of the nasal alae, without bone destruction (Figures 2).

Wide excision of $2 \mathrm{~mm}$ outside the border was performed on the tumor, frozen sectioned to verify the resection margin. The initial
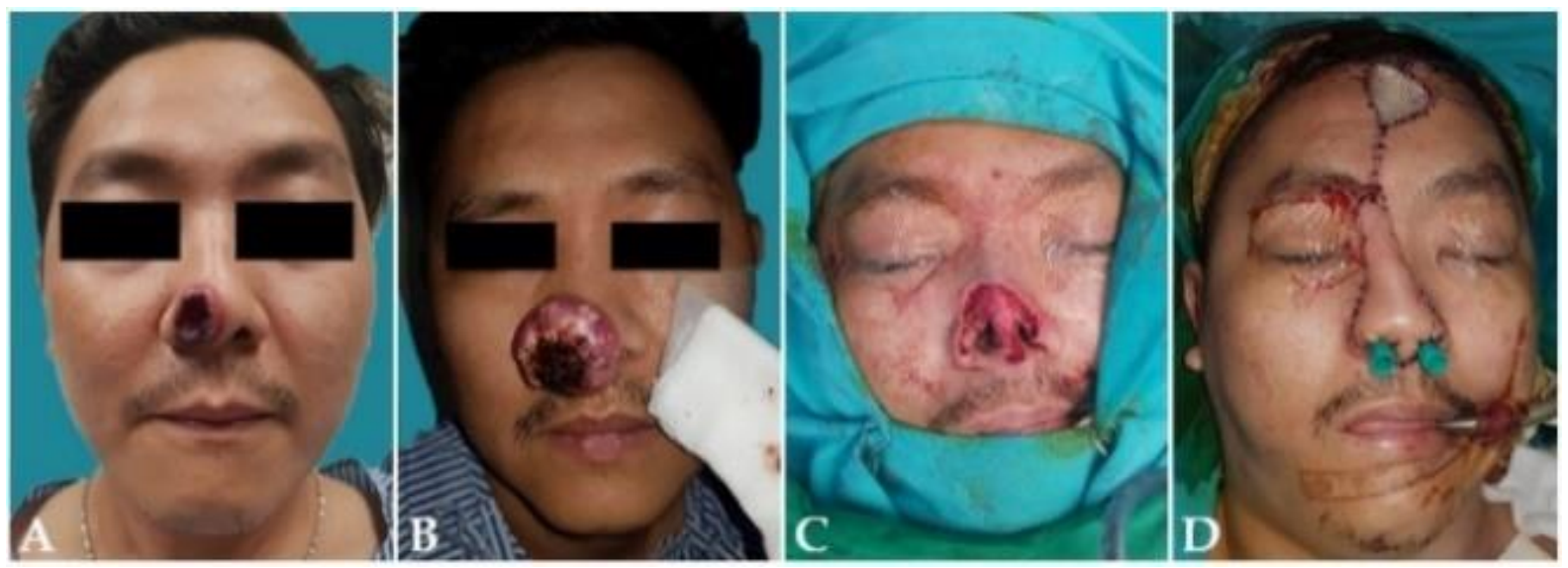

Figures 1. (A) Patient after initial debridement \& biopsy (B) Two weeks after debridement and biopsy (C) Intraoperative wide excision defect, showing loss of mucosal lining, cartilage, and skin (D) Immediate postoperative result.

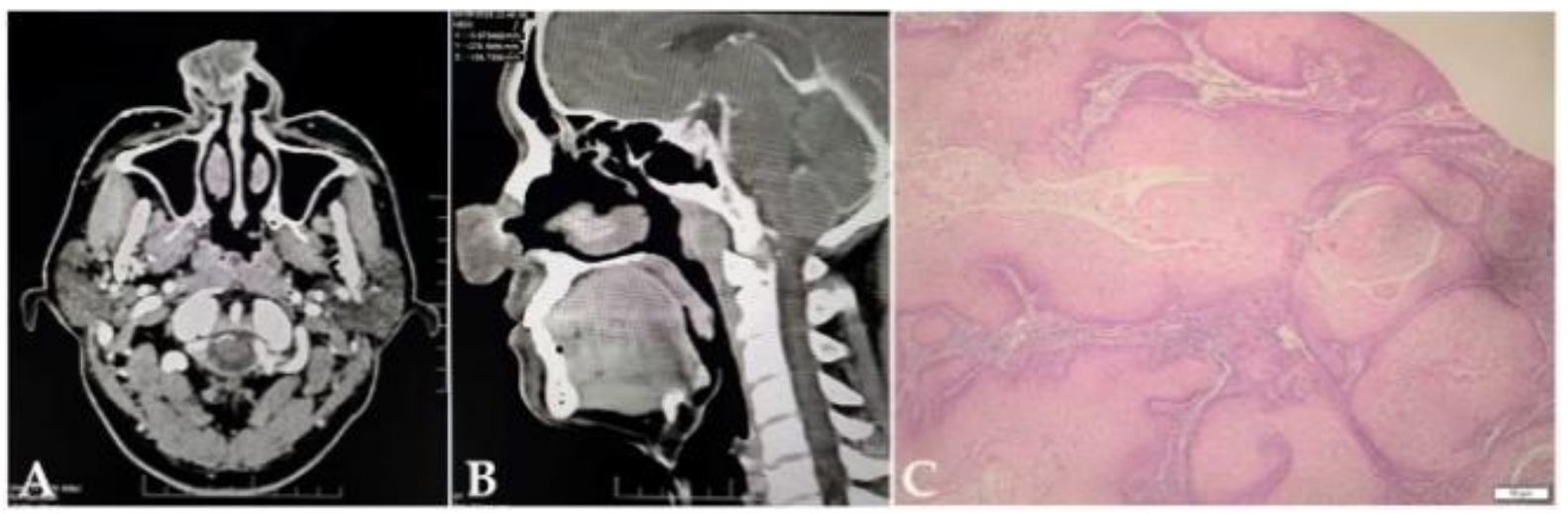

Figures 2. (A-B) CT scan of paranasal sinus, with and without IV contrast (C) Verrucous Squamous Cell Carcinoma, HE 4x, Parakeratotic centers \& hyper granulosis 


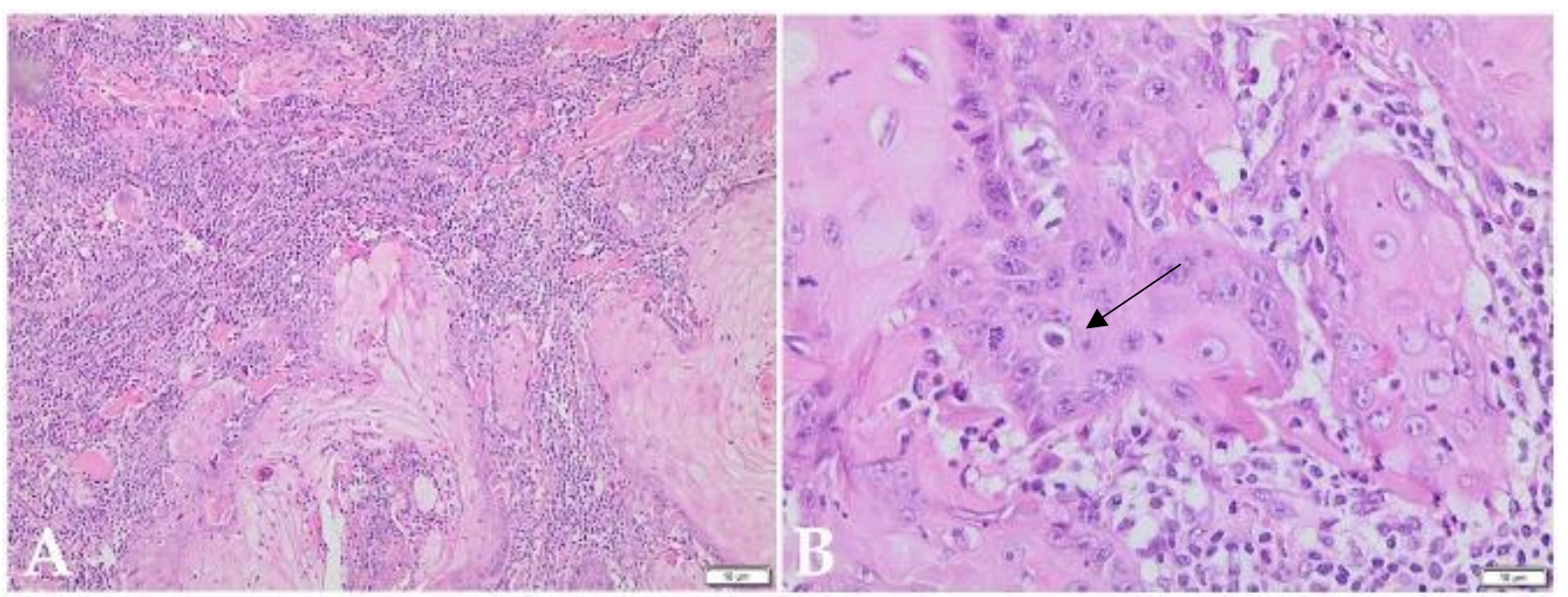

Figures 3. (A) HE 10x; Tumor cells infiltrating to stroma (B) Pleomorphic tumor cells, hyperchromatic, prominent nucleoli, visible mitosis (arrow)
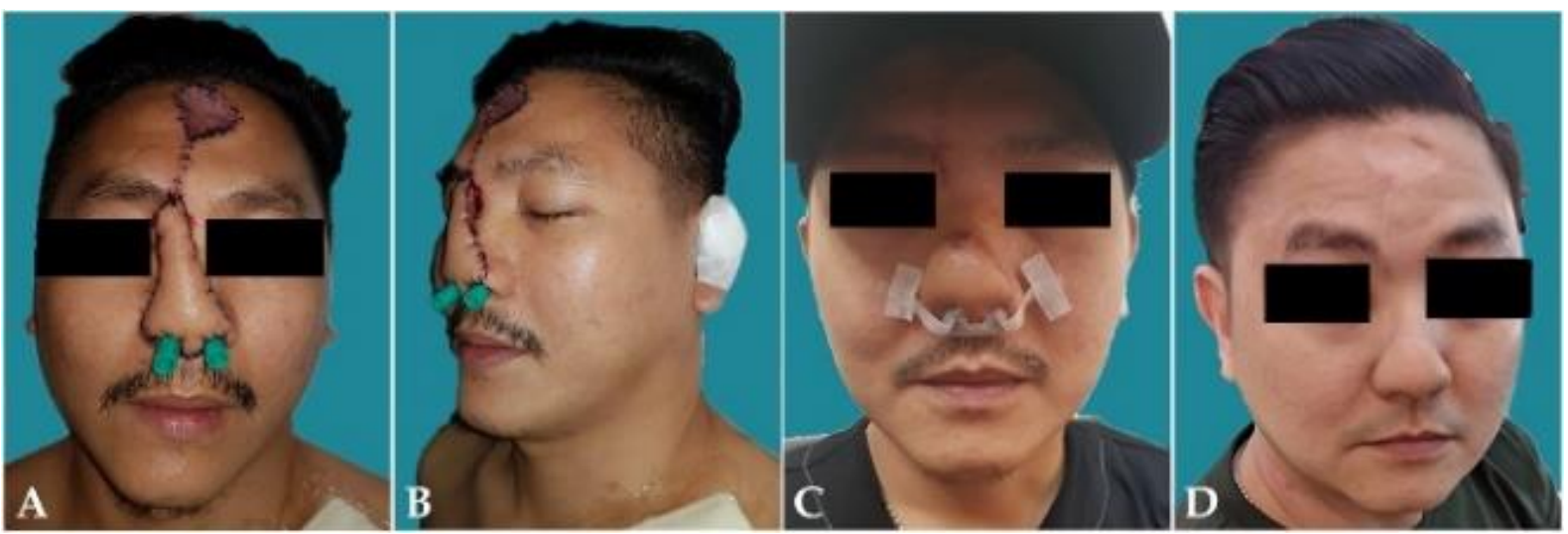

Figures 4.7 days postoperative (A) Front view (B) side view. (C) One week after second surgery with a nasal retainer for patency (D) One year after final surgery.

debridement does not include wide excision nor frozen section to ensure the margin. The excision was reconstructed layer by layer from mucosa, cartilage, and skin, with a hinged flap from the lateral side of the nose, a left auricular concha cartilage graft, and a two-step right side paramedian forehead flap, respectively. A defect of the donor forehead flap was closed with a fullthickness skin graft. The end of a nasogastric tube was then inserted into the nasal cavity to maintain airway patency. The histological examination revealed a well-differentiated verrucous squamous cell carcinoma with a tumor-free margin. (Figures 3)

Twenty days after the reconstruction, the flap bridge was cut off from the base, and a nasal retainer was used instead for maintaining patency. The patient declined radiotherapy but is now doing well with an excellent cosmetic appearance and no evidence of disease reoccurrence (Figures 4). The patient has provided written informed consent for participation in the study. The study was conducted following the Declaration of Helsinki Ethical Principles and Good Clinical Practices.

\section{DISCUSSIONS}

Verrucous carcinoma is a unique variant of squamous cell carcinoma of the skin or mucosa. There are three common forms of VC: those in the oral region (Ackerman's tumor, florid oral papillomatosis), those on genital and anal regions (giant condyloma acuminate), and those on the feet (epithelioma cuniculus). ${ }^{2-4}$ Verrucous carcinoma on the nose is rarely found, and it is usually a slow-growing tumor. ${ }^{3}$ The case described above shows the rapid growth of a verrucous carcinoma which was first identified by biopsy as inverted papilloma. Inverted 
papilloma is a benign epithelial tumor associated with squamous cell carcinoma with an incidence rate between 3 to $15.8 \% .5,6$ The tumor in the case could have been either an inverted papilloma that coexisted with verrucous carcinoma or an inverted papilloma that progressed into squamous cell carcinoma.5

This is a case of local recurrence due to inadequate margins of excision. We wondered what may have caused the fast growth of the recurred tumor. Possible causes include an immunocompromised condition or the procedure-driven recurrence. ${ }^{7}$ The patient, in this case, is immunocompetent, making immunosuppression an unlikely cause of recurrence. Biopsy and tumor resection are the gold standards for solid tumor treatment. ${ }^{8}$ Despite this, it has been suggested that surgical trauma might cause changes that promote tumor recurrence by creating an immunosuppressive environment.

Nonetheless, this statement may not be generalizable for all types of tumors. ${ }^{8}$ This report shows how verrucous carcinoma, usually a slowgrowing tumor that develops on the scale of months, ${ }^{9}$ grew in only fifteen days. However, our findings are only limited to a single case; further research on the accelerated growth of tumors that were surgically modified is needed.

Paramedian forehead flap (PFF) is the workhorse of nasal reconstruction, especially for large defects. ${ }^{10}$ Prior to the PFF, the underlying structural support must be reconstructed. The mucosal defect can be restored with a turnover hinge flap or a full-thickness skin graft for more extensive defects, vascularized by the paramedian forehead flap. Cartilage can be replaced from the antihelix and/or the concha of the ear. A composite graft of septal chondromucosal pivot flap can also be used to reconstruct both mucosa and the support structure. Cartilage prevents contraction of the underlying and overlying tissue, thus maintaining the structural integrity of the nose and airway. PFF is an axial flap that uses the supratrochlear artery as the base, usually using the contralateral side of the defect. A template of the nasal defect is usually drawn with aluminum suture packaging or sterile paper. The base is designed to be 1 to $1.5 \mathrm{~cm}$ in width to ensure the presence of the supratrochlear artery. Sterile gauze is then used to approximate the pivot point to confirm the length and design of the pedicle. The pedicle is then incised, raised, and pivoted. After ensuring the thickness of the flap is similar to that of the defect, the flap is then inset using an interrupted suture. Pedicle separation is usually done three weeks after the initial procedure to ensure neovascularization. ${ }^{10}$ No complication was found in the patient, and an excellent cosmetic appearance was achieved.

\section{SUMMARY}

We presented an unusual case of verrucous carcinoma of the nose, associated with inverted papilloma that was fast growing after it was biopsied and debrided. Further study is needed to understand the effects of mechanical forces on malignant tumors. Surgeons also have to acknowledge the side effects that may affect tumor growth after surgical trauma. This condition's delayed adequate wide excision led to recurrence and necessitated a more significant defect around the primary lesion. We emphasize how the early differential diagnosis of malignant tumors is crucial. We also showed that the twostep forehead flap is still the workhorse of nasal reconstruction and that it is able to show satisfactory cosmetic results.

\section{ACKNOWLEDGEMENT}

We thank the Department Of Pathologic Anatomy for providing the materials for the pathological specimen.

Correspondence regarding this article should be
addressed to:
Angelica Gracia Budhipramono, Faculty of Medicine, Pelita
Harapan University, Tangerang, Banten, Indonesia Jl.
Danau Ranau No. 9, Taman Beverly Golf, Lippo Village,
Tangerang 15811, Indonesia
Tel: +62-857-1635-5500 Fax: +62-21-546-9794
E-mail: angelica.gracia@live.com

\section{REFERENCES}

1. Ackerman L. Verrucous Carcinoma of the Oral Cavity. Surgery. 1948;23(4):670-8.

2. Santosh H, Nagaraj T, Saxena S, Arundhati B, Pai SA. Verrucous carcinoma: A 
clinicopathological study. J Oral Maxillofac Pathol. 2019;23(2):303.

3. Schwartz RA. Verrucous carcinoma of the skin and mucosa. J Am Acad Dermatol. 1995;32(1):1-21.

4. Chaabi M, Jaber K, Rabhi F, Abdelli W, Youssef S, Msakni I, et al. Verrucous carcinoma of the nail bed: A new case. Ski Appendage Disord. 2019;5(6):370-3.

5. Orvidas LJ, Lewis JE, Olsen KD, Weiner JS. Intranasal verrucous carcinoma: Relationship to inverting papilloma and human papillomavirus. Laryngoscope. 1999;109(3):371-5.

6. Yasumatsu R, Nakashima T, Sato M, Nakano $\mathrm{T}$, Kogo R, Hashimoto $\mathrm{K}$, et al. Clinical management of squamous cell carcinoma associated with sinonasal inverted papilloma. Auris Nasus Larynx [Internet]. 2017;44(1):98103. Available from: http:/ / dx.doi.org/10.1016/j.anl.2016.04.004

7. Stratigos A, Garbe C, Lebbe C, Malvehy J, Del Marmol V, Pehamberger $H$, et al. Diagnosis and treatment of invasive squamous cell carcinoma of the skin: European consensusbased interdisciplinary guideline. Eur J Cancer. 2015;51(14):1989-2007.

8. Alieva M, van Rheenen J, Broekman MLD. Potential impact of invasive surgical procedures on primary tumor growth and metastasis. Clin Exp Metastasis [Internet]. 2018;35(4):319-31. Available from: http:/ / dx.doi.org/10.1007/s10585-018-9896-8

9. Franklyn J, Janakiraman R, Tirkey A, Thankachan C, Muthusamy J. Oral verrucous carcinoma: Ten-year experience from a Tertiary Care Hospital in India. Indian J Med Paediatr Oncol [Internet]. 2017;38(4):452. Available from: http:/ / www.ijmpo.org/text.asp?2017/38/4/ $452 / 220141$

10.Shokri T, Kadakia S, Saman M, Habal MB, Kohlert S, Sokoya M, et al. The paramedian forehead flap for nasal reconstruction: From antiquity to present. J Craniofac Surg. 2019;30(2):330-3. 